\title{
Citizen competence and its positive influence on the learning context
}

\begin{abstract}
Summary
Learning contexts are spaces where knowledge is built, values are assimilated, skills and socio- emotional skills are developed, necessary to establish respectful relationships with others, value the plurality of humanity; contribute to the welfare of educational agents; essential for the good apprentice Aje and his emotional tranquility. ${ }^{1}$ In addition, it enables him to exercise active citizenship. In the present investigation, $\mathrm{s}$ and studies the influence of citizenship skills on the learning context, in a sample of 2 college students 35 University of Granada (Ceuta, Spain) between ages 18 and 43 years old. The positive and direct influence of the Citizen Competences on the learning context is confirmed.
\end{abstract}

Keywords: citizen competencies, contexts, learning, structural model, influence, humanistic philosophy, social justice, respect, peace, honesty, knowledge, education, social violence, exercise citizenship, learn, frameworks
Volume 2 Issue 5 - 2018

\author{
Elizabeth Zambrano Ojeda,' Juan Miguel \\ Alcántara Pilar, ${ }^{2}$ Esmeralda ${ }^{3}$ \\ 'Department of Education, University of Magdalena, Colombia \\ ${ }^{2}$ Department of Marketing and Research of Markets of \\ Education, University of Granada, Ceuta, Spain \\ ${ }^{3}$ University of Granada, Spain
}

Correspondence: Elizabeth Zambrano Ojeda, Department of Education, University of Magdalena, Santa Marta, Colombia, Email Elizabethzambrano24@gmail.com

Received: September 20, 2018 | Published: October 08, 2018

\section{Introduction}

\section{Statement of the problem/subject under study}

The social, economic, political and cultural issues that have been brewing worldwide affect the individual. One of these problems that the person must face are the tensions that make coexistence and social organization difficult, which has produced little sense of belonging and collective identity and a growing decrease in participation towards civic life. For this reason, society demands changes and expresses that it seeks to live a humanistic philosophy that evokes principles of social justice, respect, peace, honesty, service and solidarity. ${ }^{2}$ This situation is not alien to educational establishments since these are not isolated or separated from the fabric and social violence. In addition, by their nature they are complex institutions where diversity of people converges with heterogeneity of culture, reproducing actions similar to those that occur in society, which show the deterioration of interpersonal and social relationships, manifested in physical and verbal aggressions and harassment school. ${ }^{3}$ All this requires that educational institutions implement a new vision of education; being necessary and priority Going beyond the traditional paradigm of university education that is based on the teacher, based on the content, seeks the accumulation of knowledge and its success is subject to the quantity and type of knowledge developed in its context; ${ }^{4}$ For a new paradigm focused on the student, in this sense the student plays a more important role in the direction of their own learning, including reflection on him and him, it is self-directed, supported by authentic tasks in small teams and desire to learn ${ }^{5}$ which in turn leads to the responsibility of carrying out educational actions focused on the communities and their needs, which is possible if the individual is trained to exercise citizenship.

In this area, education for citizenship must form integral, active sponsors that can coexist with tolerance within a framework where democratic principles prevail ${ }^{6}$ and train them to deal with, influence and participate in such changes as right subjugation. For this reason, spaces that allow participation and decision - making on real issues

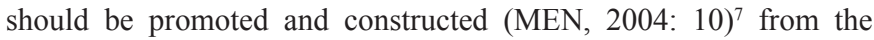
classroom to the institutional instances of the University. There is no doubt that civic education depends on the teaching staff and the learning context to promote it; with respect to the first ones, they interpret curricular reforms and specify them in the classroom; ${ }^{8}$ the seconds; they are spaces where knowledge is shared product of the cultural legacy, you learn to live the democratic principles, you acquire and practice values, you develop skills and abilities that help you to develop in the different sphere in society (political, social, labor, other), in order to transform their social environment. Our objective is to analyze the effect of citizen competencies on the learning context, starting from the importance of these, as spaces that enable not only learning; but also, as a scenario that positively influences the development of more harmonious relationships between educational agents and, therefore, in coexistence and in communication itself.

\section{Background and theoretical foundation}

The university is conceived as a learning context where you learn the knowledge necessary to exercise your social status and your role as a citizen; this last one is a challenge for the universities since it must build spaces of coexistence and of learning where the values such as dignity, justice and freedom, are present in a habitual, daily and natural way, through situations where each one of their members assume the role that corresponds to them; in order to consolidate personal, community, active and democratic lifestyles. ${ }^{9}$ To respond to this challenge, universities must assume the new educational paradigm since it emphasizes student-centered learning, recognizing it as an autonomous and critical being, training it to acquire skills, attitudes, values and competencies that contribute to its formation personal, social and collective. Involving the student to assume its role as agonist protagonist of the educational process and of the teacher, commitment in the teaching process, as mediator and articulator of good contexts and experiences of rich and constructive learning; ${ }^{10}$ In addition, the latter must use different active pedagogical practices, in order to achieve significant and relevant changes in their students and, therefore, changes in the teaching process that has been promoted in higher education institutions. In this sense, the context of learning centered on the student, gives the student the possibility to develop citizenship competencies. In this context, the student must be autonomous, participatory, problematize knowledge, extrapolate it to 
new situations in accordance with the demands and requirements of the disciplines, and reflect on the actions and attitudes that it carries out in its teaching process. On the other hand, the teacher must give the pedagogical value to the evaluation, re- signify the curriculum. ${ }^{11}$

Therefore, education must train competent individuals with the ability to know and understand social reality, to do and have an attitude in a specific context of action, skills for the full participation of the contemporary citizen, capacity to confront conflicts and value plurality and diversity of the other, ${ }^{12}$ that is, an education in and for citizenship, where students are actively involved in institutional, local and global experiences, which is possible if they develop citizen competencies. For Villarini ${ }^{13}$ citizenship competencies is the development of concepts, attitudes and skills that are required to be an active, reflective, critical and responsible member of a people that seeks to permanently organize itself as a democratic political community. In the same way, Ruiz and Chaux (2005) define citizenship competencies as the set of cognitive, emotional and communicative-integrated skills and abilities related to basic knowledge (contents, procedures, mechanisms) that morally and politically guide our citizen action (2005: 32). We understand citizenship competencies as the skill set (critical thinking, communicative and conflict resolution) to promote attitudes, actions and citizen values that lead to the empowerment of democratic principles and the exercise of effective citizenship.

In this study, two investigations were integrated, that of citizenship competences proposed by Soriano, ${ }^{14}$ which establishes three competences that are: critical, communicative and social and conflict resolution and the other of context of learning of Vigaray et al., ${ }^{15} \mathrm{In}$ the investigation of Soriano (2006), its scale measures the Citizen competences that it considers fundamental for its social and school context ; made up of 27 items, using three dimensions with a total alpha of 0.81 and for its components so critic 0.70 , Communicative and social 0, 71 and Conflict Resolution 0,72 and built in Likert Scale format with 3 options of Resentment that goes from nothing to very agree, applied to a sample of 384 high school students . The author defines citizenship competencies as follows:

The critical competence is the disposition and attitude that the person acquires to ask, question the facts, information, explanations and evaluations before analyzing them, accepting them or rejecting them. Referred to the difference and plurality of people. The communicative and social, is the strategic ability of people to act in communication situations. This competence allows sharing information with others and expressing a message in a precise language. For this it is necessary to develop a series of attitudes such as active listening and clarity, democratic responsibility and participation. The resolution of conflict is the disposition that the person has to identify and face problematic or conflicting situations in a given context, using the knowledge and strategies necessary for them and to regulate his use of them. The development of these competences encompasses the whole community as a whole, which implies that it must be included in the Institutional Educational Project; evidencing in the curricular framework, learning objectives and study programs; and its application and effectiveness requires the joint action of the different teachers and directors of each educational institution (MINEDUC, 2013) ${ }^{16}$ through the construction and promotion of democratic environments, in order to develop a new school culture among all, for guarantee a coexistence of respect, tolerance, participation and freedom.

In the study of Vigaray and González, ${ }^{15}$ my scale of the contexts of the class, in a sample of 366 students of university students consists of 23 items, with an alpha of $\alpha=0.78$ for the full scale. The instrument was constructed in a Likert Scale format with 7 response options that range from total disagreement and totally agree. The instrument consisted of the dimensions context created by the teacher, learning context, performance context, context of infrastructure to our study we only take the dimension learning contexts. E 1 learning context is defined by Gonzalez, et al, (2010) as the scenario of construction of knowledge where the process-teaching-learning is developed, influencing the attitudes that students and teachers present in terms of an educational activity. In the same way Duarte ${ }^{17}$ defines the context of learning as the space where " the educational processes are constituted and that involve actions, experiences and experiences for each one of the participants; attitudes, material conditions and socio - afectivas, multiple relationships with the environment and necessary for the realization of cultural purposes are made explicit in all educational proposal " $(2003: 8)$ infrastructure for aut or, contexts is but nimo environment, which must have the necessary conditions to promote learning and in which student and teacher develop skills, competencies, skills and values. For Donolo et al., ${ }^{18}$ the learning context is the instead the product of interaction with the physical environment and sociocultural allowing the appropriation of cultural heritage, assimilation of norms and values, "where teaching and learning takes place" allowing students to understand the social environment in which circumscribe.

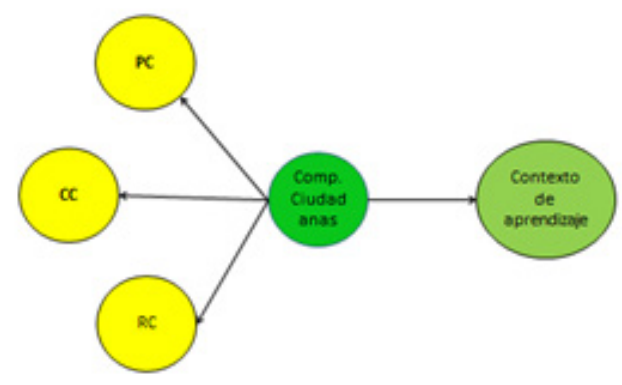

Figure I Proposed model.

This research shares the concept of learning context of Vigaray and González ${ }^{15}$ (2010, who quotes Rogoff, 1990), who defines it as the set of factors that determine the perception that the student has of the educational action, referred to both as perceptible and explicit as to not perceptible and implicit. The evidences presented by González et al. ${ }^{19}$ to state that by using the new paradigm focused on the active participation of students has as a consequence a greater degree of participation and perceived competitions in the students, in this sense, the contexts of participatory learning stimulates participation in the teaching process. The same author considers that teachers can modify behavior in their classrooms to get students to increase their skills; they can also be taught through their subjects, thus improving their learning and therefore their performance at the personal, social, moral and professional levels. These evidences confirm that students who acquire civic competences will build context favorable for learning lessons, since the context is crucial to building citizenship through reflection of the conflicting relations with its sameness, otherness and otherness, ${ }^{20}$ leading to potentiate the effect ethical, develop communicative skills, criticize and solve problems so that the student assumes an empowerment of his teaching and overlaps the public spheres. Therefore, if the student develops citizenship competencies in institutional contexts, expressing attitudes, actions and behaviors; 
and, this will positively affect the learning contexts and therefore, their learning. According to the previous findings, the following hypotheses are proposed: $\boldsymbol{H}_{1}$ The Citizenship Competences is positively related to the Learning Contexts developed in higher education. Finally, the proposed structural model corresponds to the dimensions that make up citizen competencies and their relation to the learning context (in Lisrel); that is, the effects that critical, communicative and problemsolving competences have on citizenship competences and this is on the learning context (Figure 1).

\section{Research methods}

Quantitative research on random sampling, gathered at the University of Granada Ceuta (Spain) through a self - administered between April and May 2016 questionnaire. The self - administered questionnaire was developed by students from teaching careers such as: Social education, Infant education and Primary Education, Engineering, Nursing and Business Administration. Providing a sample of 235 students, consisting of $72 \%$ for women (169 subjects)

Table I Reliability and validity of the scales used

Note $(*)$ :Value not calculated since the parameter was established at I in order to set the scale for the variable latent; B: Standardized factor loading.

\begin{tabular}{|c|c|c|c|c|c|}
\hline Variables & Codes and items & $\beta$ (t value) & $\mathbf{R 2}$ & GO & FC \\
\hline \multirow[t]{4}{*}{ Critical thinking } & $\begin{array}{l}\mathrm{PCl} \text { : I like that in class to make themselves known and cultures of my } \\
\text { colleagues who come from other countries to work. }\end{array}$ & $0.76 *$ & 0.58 & 0.69 & 0.92 \\
\hline & $\begin{array}{l}\text { PC2: Sharing the customs of other cultures, I enrich myself as a } \\
\text { person. }\end{array}$ & $0.88(11.94)$ & 0.78 & & \\
\hline & $\begin{array}{l}\text { PC3: Sharing customs among people from different cultures enriches } \\
\text { each other. }\end{array}$ & $0.96(13.27)$ & 0.92 & & \\
\hline & $\begin{array}{l}\text { PC4: Student mobility between countries is good because it enriches } \\
\text { learning. }\end{array}$ & $0.84(9.78)$ & 0.71 & & \\
\hline \multirow[t]{4}{*}{$\begin{array}{l}\text { Communicative } \\
\text { Component }\end{array}$} & $\begin{array}{l}\mathrm{CCl} \text { : We must participate openly in the debates in the classes } \\
\text { arguing our points of view. }\end{array}$ & $0.76^{*}$ & 0.54 & 0.64 & 0.87 \\
\hline & $\begin{array}{l}\text { CC2: I think it's important to connect with people from other } \\
\text { countries. }\end{array}$ & $0.95(11.93)$ & 0.9 & & \\
\hline & $\begin{array}{l}\text { CC3: The media should design their messages to be understood } \\
\text { independently of the culture and country of origin. }\end{array}$ & $0.74(10.05)$ & 0.54 & & \\
\hline & $\begin{array}{l}\text { CC4: The media should broadcast programs involving groups of } \\
\text { different cultures. }\end{array}$ & $0.72(7.19)$ & 0.5 & & \\
\hline \multirow[t]{3}{*}{ Conflict resolution } & $\begin{array}{l}\mathrm{RCI} \text { : It is not a problem that in the classrooms there are students } \\
\text { from other cultures and / or countries. }\end{array}$ & $0.7 I^{*}$ & 0.5 & 0.6 & 0.82 \\
\hline & $\begin{array}{l}\text { RC2: When there are conflicts between several colleagues in the } \\
\text { university, we must help solve it. }\end{array}$ & $0.73(5.89)$ & 0.53 & & \\
\hline & RC3: Conflicts must be resolved through dialogue. & $0.87(9.94)$ & 0.77 & & \\
\hline \multirow[t]{4}{*}{ Learning contexts } & CAI & $0.81 *$ & 0.66 & 0.72 & 0.91 \\
\hline & CA2 & $0.72(8.54)$ & 0.52 & & \\
\hline & CA3 & $0.93(14.44)$ & 0.86 & & \\
\hline & CA4 & $0.92(14.55)$ & 0.85 & & \\
\hline \multirow[t]{3}{*}{ Citizen Competencies } & Critical thinking & $0.94^{*}$ & 0.84 & 0.66 & 0.88 \\
\hline & Communicative Component & $0.95(10.88)$ & I & & \\
\hline & Conflict resolution & $0.86(7.97)$ & 0.76 & & \\
\hline
\end{tabular}

\section{Scale}

The applied measurement scales have been tested in other researches and adapted to the research needs to measure citizenship competences and the learning context.

\section{Estimation of the theoretical model and hypothesis contrast}

The estimation of the theoretical model was carried out through an and $28 \%$ for men (66 subjects ) and The average age of the students ranges from 18 to 43 years.

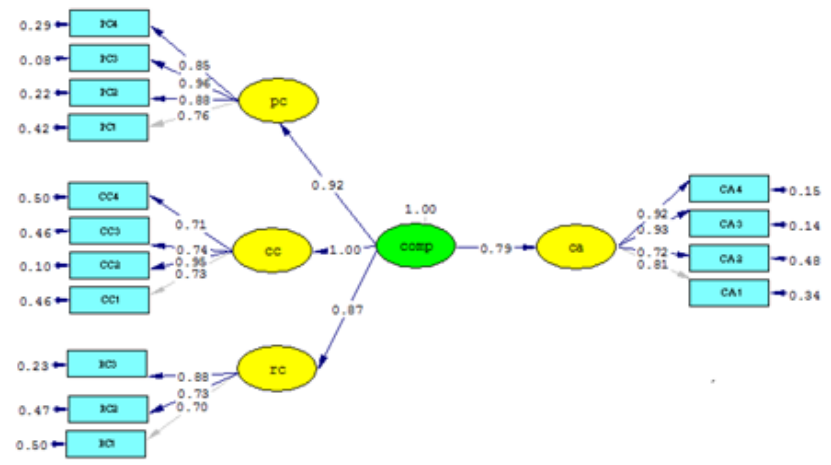

Figure 2 Estimation of the model, fully standardized parameters. 
Critical N: 242.71 (Hair et al., 2005; Del Barrio and Luque, 2012). The measurement scales used showed good psychometric properties. All factorial loads were significant $(\mathrm{p}<0.05)$ (See Table 1) and with individual reliability $\left(\mathrm{R}^{2}\right)$ in all cases above 0.50 See Table 1 . Likewise, the indexes of composite reliability (FC) and average extracted variance (AVE) were adequate above 0.70 and 0.50 , respectively. In addition, the discriminant validity of the scales used for each group was verified using the procedure suggested by Fornell and Larcker (1981) according to which the square root of the AVE must be higher than the correlation between the latent constructs see Table 2. Figure 2 shows the estimated final model. All structural relationships obtain optimal and significant reliability $\left(\mathrm{R}^{2}>0.62\right)$. The analysis of the results allows us to draw a first conclusion, The Citizenship Competencies has a direct and positive effect on the Learning Contexts developed in higher education ( $\beta: 0.79, p<0.05$ ). The student develops citizenship competencies in institutional contexts, manifesting attitudes, actions and behaviors; and, this will positively affect the learning contexts and therefore, their learning. These evidences confirm that students who acquire civic competences will build context of favorable learning for learning. ${ }^{20}$ These findings confirm the hypothesis $\mathrm{H} 1$ raised.

Table 2 Discriminant validity of the scales used

\begin{tabular}{lllll}
\hline & PC & DC & RC & AC \\
\hline & & & & \\
Pc & 0.83 & & & \\
DC & 0.89 & 0.8 & & \\
Rc & 0.81 & 0.82 & 0.77 & \\
AC & & & & 0.85 \\
\hline
\end{tabular}

\section{Conclusion}

The importance of citizen competence within the educational field is due to the demands of society and international organizations such as UNESCO, expressed through documents and statements such as the Delors ${ }^{23}$ report (1996) in which he insists on the importance of citizen education as a condition for democratic life; Alluding to the fact that learning democratic values and democratic participation prepare individuals for active citizenship. This approach is due to the lack of robustness of its institutions and practices in society and culture, ${ }^{21}$ therefore, educational institutions must develop social awareness as an essential component for the exercise of rights and citizen's duties and their participation in the different spheres that concern them, with a view to improving their living conditions. ${ }^{22}$ As a main conclusion we can consider that the model of citizen competencies can be used in research on the learning-teaching process in the new pedagogical paradigm, given that citizen education is based on communication between educational agents; in this way, free and dissenting agreements are established on certain academic and social situations, which implies carrying out actions inside and outside the institutional space; transforming the communicative process ${ }^{24}$ and the learning context; thus consolidating new habits and behaviors towards participation in the different spheres where the young person is immersed. The importance of the learning contexts lies in the fact that these allow the development of citizenship competences since they give meaning to the actions carried out in the classroom, they develop a critical awareness of the determinations that are made and their impact among the students. intentions and the consequences of their actions and influence the change of school climate and allow them to exercise a certain degree of power over the decisions made in everyday life ${ }^{18}$ assuming thus, a civic empowerment in educational institutions as well as outside it.

This research will contribute to the formation of a research line of citizen education to strengthen coexistence in the preceding education, in which conceptual frameworks are consolidated and methodological strategies designed to favor the development of concrete actions that contribute to climate improvement. institutional, emphasizing in the formation in and for the citizenship, the human rights and the democracy, the education for the peace and the values; which must transcend other environments and be ways of participation and recognition of the diversity that sustains societies (OEI, 2016). ${ }^{25-27}$ This study has some limitations that can guide future work. E 1 model should be complemented with a scale for measuring meaningful learning and / or academic performance; in order to determine if the development of civic competences affects the learning context and this in turn in the teaching, which would be obtained through an intervention program; This suggestion is due to the fact that the elements that make up citizens' competences include important factors in learning such as emotions, critical thinking and attitudes among others.

In short, universities must offer a quality education; for it, it cannot separate the professional formation of the citizen formation since this is one of its central objectives; to form people with a high human sense and responsible citizens committed to the development of human dignity; which demands to create learning contexts of permanent reflection around the life of the human being, in symbiosis with the planet and the advances of technology (Orosteguí et al, 2015).

\section{Acknowledgements}

None.

\section{Conflict of interest}

The author declares there is no conflict of interest.

\section{References}

1. Prodócimo, Elaine, Goncalves Rosaine, et al. Violencia escolar: reflexiones sobre los espacios de ocurrencia. Revista electrónica de Investigación Educativa. 2014;16(2),1-15.

2. Carrasquillo, Bangesy. Desafíos y propuestas para los ambientes de enseñanza-aprendizaje. Reidocrea. 2016;5: 97-102.

3. Medina, María. Mediación entre pares en las escuelas públicas: Una alternativa para la solución de conflictos. Revista Griot. 2015;8(1).

4. Rieckmann, Marco. Enseñanza y aprendizaje basados en competencias en la educación superior nuevos retos y condiciones para los profesores y estudiantes" In: Aguirre P, editor. La Educación basada en competencias y su contribución para el desarrollo sustentable. Göttingen. 2016;13-33.

5. Reigeluth, Charles. Teoría instruccional y tecnología para el nuevo paradigma de la educación. Revista de Educación a Distancia. 2012;32:122.

6. Carrillo, Olga. Comprendiendo la adquisición de las competencias ciudadanas en alumnos de los programas de cualificación profesional inicial. Revista Educar. 2013;49(2)207-226.

7. Gobierno de Colombia-MEN (2004), Formar para la ciudadanía ¡Sí es posible! MEN serie núm 6.

8. Muñoz Carlos, Torres Bastián. La formación ciudadana en la escuela: 
Problemas y desafíos. Revista Electrónica Educare. 2014;18(2):233-245.

9. Martínez, Miguel. Formación para la ciudadanía y educación Superior. Revista Iberoamericana de Educación. 2006;(42):85-102.

10. Gargallo, Bernardo, Jiménez Miguel. Métodos centrados en el aprendizaje, implicación del alumno y percepción del contexto de aprendizaje en estudiantes universitarios. Educación XX1. 2010.

11. Zambrano, Elizabeth Rivera Antonio Fernández Federico y González Rebeca. La práctica pedagógica constructiva: el método de caso. Memoria. 2014;12(22):81-92.

12. Gros, Begoña y Contreras David. La alfabetización digital y el desarrollo de competencias ciudadanas. Revista Iberoamericana de educación. $2006 ;(42): 103-125$

13. VillarinI Ángel. Competentes para la democracia. Una propuesta alternativa de formación ciudadana Puerto Rico: Organización para el Fomento del Desarrollo del Pensamiento. 2010.

14. Soriano, Encarna. Competencias Ciudadanas en el alumnado de segundo siclo de educación secundaria obligatoria de Almeria. Revista de Investigación Educativa. 2006;24(1):119-146.

15. Vigaray, Juan, Gascón González. Propuesta de una escala de medida de contexto de la clase In VII Jornadas de Redes de Investigación en Docencia Universitaria la calidad del proceso de enseñanza/aprendizaje universitario desde la perspectiva del cambio, 2010;739-749.

16. Gobierno de Chile - Ministerio de Educación. Orientaciones técnicas y guiones didácticos para fortalecer la formación ciudadana $7^{\circ}$ Básico a $4^{\circ}$ Medio. Santiago de Chile, MINEDUC. 2013.

17. Duarte, Jakeline. Ambientes de aprendizaje. Una aproximación conceptual Estudios Pedagógicos. 2013;(29)97-113.

18. Carolyn, Wilson. Alfabetización mediática e informacional: proyecciones didácticas. Revista Científica de Educomunicación, Comunicar. 2012;39(20):15-24.

19. González Teresa. Democracia y Formación Ciudadana. Colección cuadernos de divulgación de la Cultura Democrática: Instituto Federal Electoral de México. 2010.

20. Mieles Barrera M, y Alvarado S. Ciudadanía y Competencias ciudadana. Estudios Politicos, 40 Instituto de Estudios Politico. Universidad de Antioquia. 2012;53-75.

21. Cox, Cristian, Bascopé Martín, et al. Educación ciudadana en América Latina: Prioridades de los currículos escolares (No. 14). IBE Working Papers on Curriculum Issues. 2014. P. 1-43.

22. González, Elena De Juan, María, et al. Aprendizaje autorregulado: antecedentes y aplicación a la docencia universitaria de marketing. Revista de Investigación Educativa. 2010;28(1):171-194.

23. Delors, Jacques. La educación encierra un tesoro. Informe a la UNESCO de la Comisión Internacional sobre educación para el siglo XXI, Madrid: Ediciones UNESCO. 1996. p. 1-47.

24. Mockus, Antanas. Cultura ciudadana y comunicación. Revista La Tadeo. 2003;(68):106-111.

25. Organización de Estados Iberoamericanos-OEI- (2016). Un intercambio de experiencias iberoamericanas para conocer diversas realidades desde la práctica Convivencia escolar Redes Académicas de movilidad docente. $2015 ; 26-42$

26. Orostegui, María Lastre Gloria, Gaviria Gladys. La ética del profesor religada a la formación en valores del estudiante. Mirada teórica. Educación Humanismo. 2015;17(29):272-285.

27. Ruiz, Alexander y Chaux, Enrique. La Formación en Competencais Ciudadana, Bogotá: Ascofade. 2005. p. 1-150. 